\title{
PENGARUH CORPORATE GOVERNANCE, LEVERAGE DAN FAKTOR LAINNYA TERHADAP NILAI PERUSAHAAN NON-KEUANGAN
}

\author{
NURHAIYANI \\ STIE Trisakti \\ nurhaiyani@dosen.stietrisakti.ac.id
}

\begin{abstract}
The purpose of this study is to determine and examine the effect of corporate governance (audit committee, size of the commissioner's board, and proportion of independent commissioner's board), firm size, leverage, company growth, profitability, and dividend policy on firm value in non-financial companies listed in Indonesia Stock Exchange. This research used 76 non-financial companies listed in Indonesia Stock Exchange from the period 2013 until 2016 that were selected by using purposive sampling method. The data were analysed by using multiple linear regressions. The research results show that the proportion of independent commissioner's board, firm size, and profitability had effect towards firm value whereas the audit committee, size of the commissioner's board, leverage, company growth, and dividend policy had no effect towards firm value.
\end{abstract}

Keywords: Firm value, corporate governance, firm size, leverage, company growth, profitability.

Abstrak: Tujuan penelitian adalah untuk mengetahui dan menguji pengaruh corporate governance (komite audit, dewan komisaris, dan dewan komisaris independen), ukuran perusahaan, leverage, pertumbuhan perusahaan, profitabilitas, dan kebijakan dividen terhadap nilai perusahaan pada perusahaan non-keuangan yang terdaftar di Bursa Efek Indonesia. Penelitian ini menggunakan sampel sebanyak 76 perusahaan non-keuangan yang terdaftar di Bursa Efek Indonesia dari periode 2013 sampai 2016 yang dipilih dengan menggunakan metode purposive sampling. Data penelitian ini dianalisis dengan menggunakan metode regresi linear berganda. Hasil dari penelitian ini menunjukkan bahwa proporsi dewan komisaris independen, ukuran perusahaan, dan profitabilitas berpengaruh terhadap nilai perusahaan. Komite audit, ukuran dewan komisaris, leverage, pertumbuhan perusahaan, dan kebijakan dividen tidak memiliki pengaruh terhadap nilai perusahaan.

Kata Kunci: Nilai perusahaan, corporate governance, ukuran perusahaan, leverage, pertumbuhan perusahaan, profitabilitas

\section{PENDAHULUAN}

Persaingan dan perkembangan perusahaan pada era globalisasi semakin meningkat bukan saja di kalangan domestik namun juga di kalangan luar negeri. Persaingan yang terjadi sekarang ini banyak membuat perusahaan tidak dapat mempertahankan eksistensinya terutama bagi kalangan perusahaan domestik karena adanya peraturan pemerintah mengenai perdagangan bebas. Hal ini dapat menjadi salah satu penghambat bagi perusahaan untuk mencapai tujuan perusahaan. Tujuan perusahaan bukan hanya untuk mendapatkan laba yang tinggi tapi juga untuk 
memaksimumkan kesejahteraan pemegang saham.

Meningkatkan nilai perusahaan juga merupakan cara yang dapat digunakan untuk mengatasi persaingan dan menjaga eksistensi dari perusahaan. Nilai perusahaan dapat dipengaruhi oleh tata kelola perusahaan. Menurut Zarkasyi (2008), tata kelola perusahaan adalah serangkaian aturan yang menjelaskan hubungan antara shareholders, manajer, kreditur, karyawan, dan stakeholder internal dan eksternal lainnya dalam menjalankan tanggung jawabnya. Selain tata kelola perusahaan, perusahaan juga membutuhkan pendanaan modal untuk meningkatkan nilai perusahaan.

Nilai perusahaan dapat menjadi acuan dalam melihat perusahaan tersebut baik atau buruk. Nilai perusahaan juga menjadi perhatian utama bagi para investor. Dengan kata lain, nilai perusahaan yang menjadi indikator kinerja untuk manajer keuangan. Selain itu, nilai perusahaan adalah persepsi investor terhadap perusahaan yang biasanya terkait dengan harga saham. Harga saham yang tinggi dalam suatu perusahaan memiliki pandangan yang positif bagi investor dan mencerminkan perusahaan tersebut baik (Hidayah 2014). Kenaikan nilai yang tinggi dalam suatu perusahaan adalah tujuan jangka panjang yang harus dicapai dan akan tercermin dalam harga pasar karena penilaian investor untuk perusahaan dapat diamati melalui harga saham perusahaan yang diperdagangkan di Bursa Efek Indonesia (BEI) bagi perusahaan yang telah menjadi perusahaan publik.

Kasus yang terkait penurunan harga saham terjadi pada Blue Bird Group. Menurut Bareksa, saham emiten taksi terbesar di Indonesia menjadi salah satu top losers di papan Bursa Efek Indonesia. Saham BIRD terjun bebas hingga 58 persen sejak awal tahun 2016. Saham BIRD yang di awal tahun menempati posisi tinggi di angka Rp7.000 per lembar, harus jatuh di angka Rp2.900 per lembarnya. Hal ini dikarenakan merajalelanya aplikasi ride-sharing seperti Uber, Grab Car, dan Go Car. Perseroan terus melakukan berbagai upaya agar bisnis transportasi ini bisa bertahan hidup dengan melakukan kerjasama dengan Go-Jek dan memperbaiki aplikasi yang menyediakan pemesanan taksi secara online.

Ketidakkonsistenan dari hasil penelitian sebelumnya menjadi motivasi untuk mengambil topik ini. Tujuan penelitian ini adalah untuk memperoleh bukti empiris mengenai pengaruh komite audit, ukuran dewan komisaris, proporsi dewan komisaris independen, ukuran perusahaan, leverage, pertumbuhan perusahaan, profitabilitas dan kebijakan dividen terhadap nilai perusahaan.

\section{Teori Keagenan}

Teori keagenan pada dasarnya merupakan model yang digunakan untuk merumuskan permasalahan yang berupa konflik antara pemegang saham sebagai pemilik perusahaan (principal) dengan manajer sebagai pihak yang ditunjuk atau diberi wewenang oleh para pemegang saham (agent) untuk menjalankan perusahaan sesuai dengan kepentingannya (Sudiyatno dan Puspitasari 2010). Teori ini mengasumsikan bahwa baik agent maupun para pihak yang berkepentingan merupakan pihak yang sama-sama dapat memaksimalkan return yang akan diterima dimana kepentingan tidak terlalu dipermasalahkan. Namun pada kenyataannya, penyatuan kepentingan kedua belah pihak tersebut seringkali menimbulkan masalah yang biasa disebut sebagai masalah agensi (Onasis dan Robin 2016). Masalah agensi timbul akibat adanya pemisahan bagian kepemilikan dan konflik kepentingan antara pemilik perusahaan (pemegang saham) dengan pihak manajemen (pengelola perusahaan). Agency problem akan mempengaruhi agency cost dimana terbagi menjadi monitoring costs, bonding costs, dan residual loss (Godfrey et al. 2010, 363).

\section{Teori Sinyal}

Teori sinyal merupakan teori yang mengemukakan tentang bagaimana manajer 
dengan sukarela memberikan informasi kepada investor sebagai bentuk sinyal agar investor dapat mengambil keputusan. Sinyal ini dapat berupa informasi mengenai apa yang sudah dilakukan oleh manajemen untuk merealisasikan keinginan pemilik dan juga dapat berupa promosi atau informasi lain yang menyatakan bahwa perusahaan lebih baik daripada perusahaan lain. Pada teori sinyal, manajer berperan sebagai pihak yang memberikan informasi bahwa perusahaan dalam keadaan akan memperoleh keuntungan investor akan memperoleh insentif jika investor mempercayai informasi tersebut. Hal ini akan mempengaruhi peningkatan nilai saham dan memberikan keuntungan terhadap investor dan manajer (Godfrey et al. 2010, 375).

\section{Komite Audit dan Nilai Perusahaan}

Komite audit merupakan penghubung antara manajemen perusahaan dengan dewan komisaris maupun pihak eksternal lainnya sebab penggunaan komite audit merupakan usaha perbaikan terhadap cara pengelolaan perusahaan terutama cara pengawasan terhadap manajemen perusahaan (Sari dan Ardiana 2014). Komite audit memonitor mekanisme yang meningkatkan kualitas arus informasi antara pemegang saham dan manajer (Rouf 2012) yang pada gilirannya membantu meminimalkan agency problem. Jika komite audit telah bekerja dengan baik dan efektif, maka kontrol dari perusahaan juga akan baik. Ketika kontrol perusahaan sudah baik barulah dewan komisaris turut andil dalam pengawasan (Siahaan 2013). Hipotesis yang diajukan adalah: $\mathrm{H}_{1}$ Komite audit bepengaruh terhadap nilai perusahaan

\section{Ukuran Dewan Komisaris dan Nilai Perusahaan}

Dewan komisaris merupakan pihak yang bertanggung jawab memiliki otoritas penuh dalam membuat keputusan sesuai dengan tujuan perusahaan. Puncak sistem operasional internal perusahaan dipegang oleh dewan komisaris yang mempunyai peranan penting dalam menyediakan laporan keuangan yang reliable dan pengawasan operasional perusahaan, dimana dewan komisaris memegang kendali dalam menentukan keputusan dan kebijakan yang akan dilaksanakan perusahaan (Purbopangestu dan Subowo 2014). Hipotesis yang diajukan adalah: $\mathrm{H}_{2}$ Ukuran dewan komisaris berpengaruh terhadap nilai perusahaan

\section{Proporsi Dewan Komisaris Independen dan Nilai Perusahaan}

Menurut Kusumaningtyas dan Andayani (2015), komisaris independen adalah anggota dewan komisaris yang tidak terafiliasi dengan manajemen, anggota dewan komisaris lainnya dan pemegang saham pengendali, bebas dari hubungan bisnis atau hubungan lainnya yang dapat mempengaruhi kemampuannya untuk bertindak independen atau bertindak semata-mata sesuai kepentingan perusahaan. Hipotesis yang diajukan adalah:

$\mathrm{H}_{3}$ Proporsi dewan komisaris independen berpengaruh terhadap nilai perusahaan

\section{Ukuran Perusahaan dan Nilai Perusahaan}

Ukuran perusahaan dapat didefinisikan seberapa besar atau kecilnya suatu perusahaan yang direpresentasikan dengan aset, angka penjualan, rata-rata total penjualan, dan ratarata total aset (Putu et al. 2014). Ukuran perusahaan dapat menentukan nilai perusahaan. Semakin besar ukuran perusahaan, maka perusahaan dianggap semakin mudah mendapatkan sumber pendanaan untuk memaksimumkan kegiatan operasional (Pantow et al. 2015). Menurut Novari dan Lestari (2016), ukuran perusahaan dapat menjadi acuan untuk menentukan tingkat kepercayaan investor. Semakin besar suatu perusahaan, maka semakin dikenal oleh masyarakat yang berarti semakin mudah untuk mendapatkan informasi yang akan 
meningkatkan nilai perusahaan. Hipotesis yang diajukan adalah:

$\mathrm{H}_{4}$ Ukuran perusahaan berpengaruh terhadap nilai perusahaan

\section{Leverage dan Nilai Perusahaan}

Leverage merupakan hal yang penting dalam mengukur efektivitas dari hutang perusahaan. Menurut Sambora et al. (2014), leverage merupakan tingkat kemampuan perusahaan dalam memenuhi kewajibannya untuk membayar hutang. Pengertian dari leverage sendiri adalah dana yang menanggung beban (biaya) tetap, baik dana yang berupa real asset maupun financial asset. Perusahaan menggunakan rasio leverage dengan tujuan agar keuntungan yang diperoleh lebih besar daripada biaya asset dan sumber dananya, dengan demikian akan meningkatkan keuntungan pemegang saham. Kemampuan perusahaan menggunakan aktiva atau dana untuk memperbesar tingkat penghasilan (return) bagi pemilik perusahaan dengan memperbesar tingkat leverage maka hal ini akan berarti bahwa tingkat ketidakpastian (uncertainty) dari return yang akan diperoleh akan semakin tinggi pula, tetapi pada saat yang sama hal tersebut akan memperbesar jumlah return yang akan diperoleh. Hipotesis yang diajukan adalah:

$\mathrm{H}_{5}$ Leverage berpengaruh terhadap nilai perusahaan

\section{Pertumbuhan Perusahaan dan Nilai Perusahaan}

Pertumbuhan perusahaan adalah salah satu tujuan yang diharapkan dari pihak internal maupun pihak eksternal perusahaan yang akan membawa pengaruh baik bagi perusahaan. Pertumbuhan perusahaan juga dapat menarik perhatian investor, kreditur, maupun shareholders yang dapat diukur berdasarkan perubahan dari total asset dan penjualan perusahaan. Semakin besar tingkat pertumbuhan perusahaan, maka semakin tinggi biaya yang diperlukan untuk investasi
(Sembiring dan Pakpahan 2010). Hipotesis yang diajukan adalah:

$\mathrm{H}_{6}$ Pertumbuhan perusahaan berpengaruh terhadap nilai perusahaan

\section{Profitabilitas dan Nilai Perusahaan}

Menurut Mayogi dan Fidiana (2016), profitabilitas merupakan ukuran dari kemampuan perusahaan memperoleh laba dalam hubungannya dengan penjualan, total aktiva maupun modal sendiri. Profitabilitas sangat diperhatikan oleh para calon investor maupun pemegang saham karena berkaitan dengan harga saham serta dividen yang akan diterima. Jika perusahaan mendapatkan laba sebagai timbal balik, pemegang saham akan mendapat dividen. Profitabilitas adalah tolak ukur dalam menentukan alternatif pembiayaan. Kenaikan profit suatu perusahaan dapat meningkatkan harga pasar yang menyebabkan capital gain. Profit juga sangat berpengaruh terhadap kreditur untuk mempertimbangkan pemberian pinjaman. Pihak manajemen perusahaan sering menggunakan profit sebagai acuan dalam melihat kinerja perusahaan. Semakin tinggi profit yang dihasilkan suatu perusahaan, maka kinerja perusahaan juga semakin tinggi yang berdampak terhadap kenaikan nilai perusahaan (Nasehah dan Widyarti 2012). Hipotesis yang diajukan adalah: $\mathrm{H}_{7}$ Profitabilitas berpengaruh terhadap nilai perusahaan

\section{Kebijakan Dividen dan Nilai Perusahaan}

Kebijakan dividen adalah suatu rencana mengenai tindakan yang akan diambil oleh perusahaan dalam membuat keputusan dividen. Jadi, kebijakan dividen merupakan hal yang penting menyangkut apakah arus kas akan dibayarkan kepada para pemegang saham atau akan ditahan untuk diinvestasikan kembali oleh perusahaan. Jika dibayarkan kepada para pemegang saham, besarnya dividen yang dibagikan tergantung kepada kebijakan masingmasing perusahaan. Kebijakan dividen dalam suatu perusahaan merupakan hal yang 
kompleks karena melibatkan kepentingan banyak pihak. Perusahaan harus dapat mempertimbangkan kebijakan ini dengan sebaik-baiknya agar tidak ada pihak yang dirugikan (Gitman dan Zutter 2015, 614). Hipotesis yang diajukan adalah:

$\mathrm{H}_{8} \quad$ Kebijakan dividen berpengaruh terhadap nilai perusahaan

\section{METODE PENELITIAN}

Populasi yang digunakan dalam penelitian ini adalah perusahaan non-keuangan yang secara konsisten terdaftar di Bursa Efek Indonesia (BEl) dengan periode penelitian selama 4 tahun, yaitu pada tahun 2013-2016 sebanyak 362 perusahaan. Hasil dari proses sampel dengan menggunakan teknik purposive sampling dapat dilihat pada tabel diabawah ini:

Tabel 1 Kriteria Pemilihan Sampel

\begin{tabular}{|c|c|c|}
\hline Keterangan & Jumlah & Data \\
\hline $\begin{array}{l}\text { Perusahaan non-keuangan yang terdaftar di Bursa Efek } \\
\text { Indonesia periode 2012-2016. }\end{array}$ & 362 & 1.448 \\
\hline $\begin{array}{l}\text { Perusahaan non-keuangan yang tidak menerbitkan laporan } \\
\text { keuangan tahunan yang berakhir pada tanggal } 31 \\
\text { Desember. }\end{array}$ & (7) & $(28)$ \\
\hline $\begin{array}{l}\text { Perusahaan non-keuangan yang tidak menyajikan laporan } \\
\text { keuangan dalam bentuk mata uang rupiah. }\end{array}$ & (67) & (268) \\
\hline $\begin{array}{l}\text { Perusahan non-keuangan yang tidak menghasilkan laba } \\
\text { secara konsisten selama periode } 2012-2016 \text {. }\end{array}$ & (121) & $(484)$ \\
\hline $\begin{array}{l}\text { Perusahan non-keuangan yang tidak membagikan dividen } \\
\text { secara konstan pada periode } 2013-2016 \text {. }\end{array}$ & (75) & (300) \\
\hline $\begin{array}{l}\text { Perusahaan non-keuangan yang melakukan stock split } \\
\text { selama periode } 2013-2016 \text {. }\end{array}$ & (16) & (64) \\
\hline Total sampel penelitian & 76 & 304 \\
\hline
\end{tabular}

Nilai perusahaan dalam penelitian ini diadaptasi dari penelitian Siahaan (2013) yang diukur dengan skala rasio menggunakan Price Book Value (PBV). Price Book Value (PBV) merupakan rasio antara harga pasar dan nilai buku dari saham

Komite audit diukur jumlah komite audit. Ukuran dewan komisaris diukur jumlah total anggota dewan komisaris dalam suatu perusahaan (Firdausyah et al. 2013). Menurut Alfinur 2016, dewan komisaris independen haruslah netral dimana tidak memihak siapapun dalam perusahaan. Jumlah komisaris independen harus dapat menjamin agar mekanisme pengawasan berjalan secara efektif dan sesuai dengan peraturan perundang- undangan. Menurut Sofyaningsih dan Hardiningsih (2011), aset merupakan tolak ukur besaran atau skala suatu perusahaan. Pada umumnya perusahaan besar mempunyai aset yang besar pula nilainya. Ukuran perusahaan diukur dengan log total aset. Leverage diukur dengan skala rasio menggunakan Debt Ratio. Rasio ini membandingkan antara total hutang dengan total aset (Siahaan 2013). Jadi, tujuan dari rasio ini adalah untuk menunjukkan sejauh mana aset perusahaan dapat menutupi hutang perusahaan (Khumairoh et al.2016). Tingkat pertumbuhan diukur dengan perubahan dari total aset dari suatu periode (tahun) ke periode lain berikutnya. Pada penelitian ini, Pengukuran pertumbuhan perusahaan mengacu pada Safitri 
dan Suwitho (2015) dengan pertumbuhan aset. Profitabilitas dapat diukur dengan skala rasio menggunakan Return On Equity (ROE), dimana return on equity (ROE) merupakan rasio kemampuan perusahaan dalam menghasilkan keuntungan untuk pemegang saham. Return on equity (ROE) dilakukan dengan membandingkan laba sebelum pajak dan total ekuitas. Menurut Winarto (2015), kebijakan dividen dapat diukur dengan skala rasio menggunakan Dividend Payout Ratio (DPR).
DPR menunjukkan perbandingan antara dividen yang dibagikan oleh perusahaan dengan laba bersih yang dihasilkan oleh perusahaan.

\section{HASIL PENELITIAN}

Berikut ini disajikan mengenai hasil statistik deskriptif dan hasil pengujian hipotesis setiap variabel yang digunakan dalam penelitian.

Tabel 2 Statistik Deskriptif

\begin{tabular}{lccccc}
\hline Variabel & $\mathbf{N}$ & Minimum & Maksimum & Mean & Std. Deviation \\
\hline PBV & 304 & 0.291478 & 62.931072 & 3.02999295 & 6.417125122 \\
AC & 304 & 2.000000 & 6.000000 & 3.18421053 & 0.519215613 \\
BCSIZE & 304 & 2.000000 & 22.000000 & 5.18092105 & 2.609356952 \\
PIBC & 304 & 0.166667 & 1.000000 & 0.40069760 & 0.123457582 \\
FSIZE & 304 & 11.192074 & 14.418061 & 12.69044125 & 0.653760740 \\
LEV & 304 & 0.069879 & 0.840709 & 0.43547182 & 0.180350383 \\
CG & 304 & -0.200079 & 1.416601 & 0.14621342 & 0.169596435 \\
ROE & 304 & 0.003852 & 1.358487 & 0.16596843 & 0.157544444 \\
DPR & 304 & 0.000399 & 4.524949 & 0.36097877 & 0.404419501 \\
\hline
\end{tabular}

Tabel 3 Hasil Uji t

\begin{tabular}{lll}
\hline \multicolumn{1}{c}{ Variabel } & B & Sig. \\
\hline (Constant) & -19.486 & 0.000 \\
AC & -0.017 & 0.962 \\
BCSIZE & 0.026 & 0.741 \\
PIBC & 6.339 & 0.000 \\
FSIZE & 1.098 & 0.000 \\
LEV & 1.107 & 0.284 \\
CG & -1.560 & 0.154 \\
ROE & 33.112 & 0.000 \\
DPR & 0.586 & 0.203 \\
\hline
\end{tabular}

Komite audit tidak berpengaruh terhadap nilai perusahaan. Hal ini dapat disebabkan adanya keberadaan komite audit belum tentu dapat menjamin kinerja perusahaan akan lebih baik, sehingga pasar akan berasumsi bahwa keberadaan komite audit tidak menjadi faktor untuk mereka memperimbangkan nilai suatu perusahaan baik atau buruk (Siahaan 
2013). Ukuran dewan komisaris tidak berpengaruh secara individual terhadap nilai perusahaan. Hal ini disebabkan besar kecilnya dewan komisaris tidaklah menjadi faktor penentu utama dari efektivitas pengawasan terhadap manajemen perusahaan. Fungsi dewan komisaris dalam perusahaan hanyalah sebagai controller dan tidak terlibat langsung dengan kegiatan operasional perusahaan sehingga tidak terlalu berpengaruh dengan nilai suatu perusahaan (Wardoyo dan Veronica 2013).

Proporsi dewan komisaris independen berpengaruh terhadap nilai perusahaan pada perusahaan. Hal ini karena adanya mekanisme kontrol yang kuat dari komisaris independen terhadap manajemen, dimana mekanisme kontrol tersebut merupakan peran vital bagi terciptanya tata kelola perusahaan yang baik (Alfinur 2016). Ukuran perusahaan berpengaruh positif terhadap nilai perusahaan. Hal ini dapat disebabkan ukuran perusahaan dijadikan patokan bahwa perusahaan tersebut memiliki kinerja yang bagus, sehingga ukuran perusahaan bisa memberikan pengaruh yang positif terhadap nilai perusahaan (Nurhayati 2013).

Leverage tidak berpengaruh secara individual terhadap nilai perusahaan. Hal ini disebabkan sebagai besar investor saham tidak begitu memperhatikan leverage karena leverage cenderung tidak berpengaruh terhadap harga saham di pasar modal. Leverage hanya dianggap investor sebagai tingkat kemampuan perusahaan dalam melunasi hutang-hutangnya (Sambora et al. 2014). Pertumbuhan perusahaan tidak berpengaruh secara individual terhadap nilai perusahaan. Hal ini disebabkan semakin tinggi tingkat pertumbuhan perusahaan maka semakin sedikit dana yang tersedia untuk dibagikan kepada pemegang saham. Para investor lebih percaya kepada perusahaan yang sudah mapan dan tidak sedang bertumbuh.
Oleh karena itu walaupun tingkat pertumbuhan perusahaan tinggi, tidak akan mempengaruhi kepercayaan investor sehingga tidak akan pula mempengaruhi tingkat $P B V$ suatu perusahaan (Nasehah dan Widyarti 2012).

Profitabilitas berpengaruh secara individual terhadap nilai perusahaan. Hal ini disebabkan prospek perusahaan dan kinerja perusahaan yang baik dapat ditunjukkan melalui tingginya laba atau keuntungan yang dihasilkan oleh suatu perusahaan. Ketika perusahaan memiliki laba yang tinggi, para investor akan mulai melirik perusahaan tersebut karena investor memandang perusahaan yang berlaba tinggi akan memberikan return yang tinggi pula. Hal ini dapat menyebabkan meningkatnya harga saham perusahaan tersebut yang berdampak juga pada kenaikan nilai perusahaan tersebut (Thaharah dan Asyik 2016). Kebijakan dividen tidak berpengaruh secara individual terhadap nilai perusahaan. Hal ini dikarenakan dividen sebagai sinyal yang tidak direspon positif oleh pasar dan bisa disebabkan kepemilikan saham pada perusahaan yang terdaftar di Bursa Efek Indonesia sebagian dimiliki oleh kelompok tertentu sehingga investor tidak sensitif terhadap keputusan dividen (Wardjono 2010).

\section{PENUTUP}

Setelah melakukan analisis dan pembahasan dengan sampel penelitian perusahaan non-keuangan yang terdaftar secara konsisten di Bursa Efek Indonesia selama tahun 2013 sampai dengan tahun 2016, dapat disimpulkan bahwa proporsi dewan komisaris independen, ukuran perusahaan, dan profitabilitas berpengaruh terhadap nilai perusahaan. Komite audit, ukuran dewan komisaris, leverage, pertumbuhan perusahaan dan kebijakan dividen tidak berpengaruh terhadap nilai perusahaan. 


\section{REFERENSI:}

Alfinur. 2016. Pengaruh Mekanisme Good Corporate Governance (GCG) terhadap Nilai Perusahaan pada Perusahaan yang Listing di BEl. Jurnal Ekonomi Modernisasi, Vol. 12 No. 1: 44-50.

Bareksa, 9 Desember 2016, Tertekan Taksi Online, Blue Bird Masuk 10 Saham Terburuk 2016, diakses 16 Maret 2017 dari http://www.bareksa.com/id/text/2016/12/09/tertekan-taksi-online-blue-birdmasuk-10-saham-terburuk-2016-siapa-lainnya/14448/news

Firdausya, Zanera Saroh, Fifi Swandari, Widyar Effendi. 2013. Pengaruh Mekanisme Good Corporate Governance (GCG) pada Nilai Perusahaan (Studi pada Perusahaan yang Masuk Indeks LQ 45 di Bursa Efek Indonesia). Jurnal Wawasan Manajemen, Vol. 1 No. 3: 407-423.

Gitman, Lawrence J. and Chad J. Zutter. 2015. Principles of Managerial Finance, 14th edition. England: Pearson.

Godfrey, Jane, Allan Hodgson, Ann Tarca, Jane Hamilton, Scott Holmes. 2010. Accounting Theory, $7^{\text {th }}$ edition. America: John Willey\&Sons, Inc.

Hidayah, Nurul. 2014. The Effect of Company Characteristic Toward Firm Value in the Property and Real Estate Company in Indonesia Stock Exchange. International Journal of Business, Economics and Law, Vol. 5 No. 1: 1-8.

Khumairoh, Nawang Kalbuana, Henny Mulyati. 2016. Pengaruh Leverage, Profitabilitas, dan Ukuran Perusahaan terhadap Nilai Perusahaan. Syariah Paper Accounting FEB UMS, ISSN 2460-0784: 71-81.

Kusumaningtyas, Titah Kinanti, Andayani. 2015. Pengaruh Good Corporate Governance terhadap Nilai Perusahaan yang Terdaftar pada Indeks Sri-Kehati. Jurnal IImu \& Riset Akuntansi, Vol. 7 No. 7.

Mayogi, Dien Gusti, Fidiana. 2016. Pengaruh Profitabilitas, Kebijakan Dividen dan Kebijakan Utang terhadap Nilai Perusahaan. Jurnal Ilmu dan Riset Akuntansi, Vol. 5 No. 1: 1-18.

Nasehah, Durrotun, Endang Tri Widyarti. 2012. Analisis Pengaruh ROE, DER, DPR, Growth, dan Firm Size terhadap Price to Book Value (PBV). Diponegoro Journal of Management, Vol. 1 No. 1: 1-9.

Nurhayati, Mafizatun. 2013. Profitabilitas, Likuiditas dan Ukuran Perusahaan Pengaruhnya terhadap Kebijakan Dividen dan Nilai Perusahaan Sektor Non Jasa. Jurnal Keuangan dan Bisnis, Vol. 5 No. 2: 144-153.

Novari, Putu Mikhy, Putu Vivi Lestari. 2016. Pengaruh Ukuran Perusahaan, Leverge, dan Profitabilitas terhadap Nilai Perusahaan pada Sektor Properti dan Real Estate. Jurnal Manajemen Unud, Vol. 5 No. 9: 5671-5694.

Onasis, Kristie, Robin. 2016. Pengaruh Tata Kelola Perusahaan terhadap Nilai Perusahaan pada Perusahaan Sektor Keuangan yang Terdaftar di BEI. Bina Ekonomi, Vol. 20 No. 1:1-22.

Pantow, Mawar Sharon R., Sri Murni, Irvan Trang. 2015. Analisa Pertumbuhan Penjualan, Ukuran Perusahaan, Return On Asset, dan Struktur Modal terhadap Nilai Perusahaan yang Tercatat di Indeks LQ 45. Jurnal EMBA, Vol. 3 No. 1: 961-971.

Purbopangestu, H. Wisnu, Subowo. 2014. Pengaruh Good Corporate Governance terhadap Nilai Perusahaan dengan Corporate Social Responsibility sebagai Variabel Intervening. Accounting Analysis Journal, Vol. 3 No. 3: 321-333.

Putu, Ni Nyoman G. Martini, Moeljadi, Djumahir, Atim Djazuli. 2014. Factors Affecting Firms Value of Indonesia Public Manufacturing Firms. International Journal of Business and Management Invention, Vol. 3 No. 2: 35-44.

Rouf, Abdur. 2012. The Relationship between Corporate Governance and Value of the Firm in Developing Countries: Evidence from Bangladesh. Journal of Economics and Business Research, Vol. 18 No. 1: 73-85. 
Safitri, Hazlina, Suwitho. 2015. Pengaruh Size, Growth, dengan Kebijakan Dividen sebagai Variabel Monitoring terhadap Nilai Perusahaan. Jurnal IImu dan Riset Manajemen, Vol. 4 No. 6: 1-15.

Sambora, Mareta Nurjin, Siti Ragil Handavani, Sri Mangesti Rahayu. 2014. Pengaruh Leverage dan Profitabilitas terhadap Nilai Perusahaan (Studi Perusahaan Food and Beverages yang Terdaftar di BEl). Jurnal Administrasi Bisnis (JAB), Vol. 8 No. 1: 1-10.

Sari, A.A Pt. Agung Mirah Purnama, Putu Agus Ardiana. 2014. Pengaruh Board Size terhadap Nilai Perusahaan. E-Jurnal Akuntansi Universitas Udayana, Vol. 7 No. 1: 177-191.

Sembiring, Etti Ernita, Rosma Pakpahan. 2010. Pengaruh Kebijakan Dividen terhadap Nilai Perusahaan pada Perusahaan Manufaktur yang Terdaftar di Bursa Efek Indonesia. Ekspansi Jurnal Ekonomi, Keuangan, Perbankan, dan Akuntansi, Vol. 2 No.1: 47-56.

Siahaan, Fadjar O.P., 2013. The Effect of Good Corporate Governance Mechanism, Leverage, and Firm Size on Firm Value. GSTF Journal on Business Review (GBR), Vol. 2 No.4: 137-142.

Sofyaningsih, Sri, Pancawati Hardiningsih. 2011. Struktur Kepemilikan, Kebijakan Dividen, Kebijakan Hutang dan Nilai Perusahaan. Dinamika Keuangan dan Perbankan, Vol. 3 No. 1: 68-87.

Sudiyatno, Bambang, Elen Puspitasari. 2010. Pengaruh Kebijakan Perusahaan terhadap Nilai Perusahaan dengan Kinerja Perusahaan sebagai Variabel Intervening (Studi pada Perusahaan Manufaktur di Bursa Efek Indonesia). Dinamika Keuangan dan Perbankan, Vol. 2 No. 1: 1-22.

Thaharah, Nina, Nur Fadjrih Asyik. 2016. Pengaruh Mekanisme Corporate Governance dan Kinerja Keuangan terhadap Nilai Perusahaan LQ 45. Jurnal IImu dan Riset Akuntansi, Vol. 5 No. 2:1-18.

Wardjono. 2010. Analisis Faktor-Faktor yang Mempengaruhi Price Book Value dan Implikasinya pada Return Saham. Dinamika Keuangan dan Perbankan, Vol. 2 No. 1: 83-96.

Wardoyo dan Theodora Martina Veronica. 2013. Pengaruh Good Corporate Governance, Corporate Social Responsibility dan Kinerja Keuangan Terhadap Nilai Perusahaan. Jurnal Dinamika Manajemen. Vol. 4, No. 2, hlm. 132-149.

Winarto, Jacinta. 2015. The Determinants of Manufacturer Firm Value in Indonesia Stock Exchange. International Journal of Information, Business and Management, Vol. 7 No. 4: 323-349.

Zarkasyi, Moh. Wahyudin. 2008. Good Corporate Governance pada Badan Usaha Manufaktur, Perbankan, dan Jasa Keuangan Lainnya. Bandung: Alfabeta. 
